\title{
Applying of length shoots to Determine the Success of Grafting to Effort Supplying of Citrus Plant Seedling
}

\author{
Ida Bagus Komang Mahardika ${ }^{1}$, Ni Putu Anom Sulistiawati ${ }^{2}$, Ni Komang Alit Astiari ${ }^{3}$ \\ $\left\{\right.$ Gusmahardika62@gmail.com ${ }^{1}$ \}
}

Department of Agrotechnology, Faculty of Agriculture Warmadewa University ${ }^{123}$

\begin{abstract}
Increasing population, yield and quality of citrus fruit can be done through the provision of seedling by grafting method. Grafting is an activity to combine two or more superior properties in one plant. This study aims to determine the effect of entres length on the results of grafting of citrus plants in an effort to provide seeds. This research was carried out using planting media in pots (polybags) as a place to plant seeds. The study was conducted in Belancan village, Kintamani Subdistrict, Bangli Regency with altitude of 500 meters above sea level started from June to September 2018. This study used a Randomized Block Design with 2 factors arranged factorially. The first factor tested was the treatment of entres length, namely: $\mathrm{E} 1=1 \mathrm{~cm}, \mathrm{E} 2=2 \mathrm{~cm}, \mathrm{E} 3=3 \mathrm{~cm}, \mathrm{E} 4=4 \mathrm{~cm}$ and $\mathrm{E} 5=5 \mathrm{~cm}$, while the second factor that was tested were the varieties of citrus plants consisting of JB $=$ pomelo and JS $=$ tangerines. So that, there were 10 combinations of treatments with 3 replications. The variables observed were: the start of shoots, length of shoots, leaf number of shoots, wet shoot weight and shoot dry weight. The results showed that there was no interaction factor significant effect on most variables, excepted for the variable wet weight of shoots, and dry weight of shoots. The best seed yield was obtained at $5 \mathrm{~cm}$ enteres length treatment on pomelo varieties, namely the start of shoots on 12,93 days after paste, shoot length of $43.33 \mathrm{~cm}$, number of shoots were 22,00 strands, wet weight of shoots of $56,97 \mathrm{~g}$, and dry weight shoot of $18.20 \mathrm{~g}$.
\end{abstract}

Keywords: Orange Seedling, Length of Entres, Pomelo, Tangerine.

\section{Introduction}

The availability of sufficient seeds in good quantity and quality is the main requirement in citrus cultivation to increase population and productivity. The success of the cultivation of fruit trees, especially those with large commercial scale is determined by the availability of quality seeds at the right time, in large quantities and at prices affordable to farmers. The use of seeds and varieties that are not suitable will cause difficulties in managing the next crop. This error will usually be felt a few years later, that is, after the plants have produced (Hatta et al., 1992). Therefore, research and development and management of existing nursery gardens need to be improved in order to meet the growing demand for seed consumers (Samekto, et al., 1995). Commercially cultivated citrus plants generally use seeds from grafting [1]. In Indonesia, grafting is a commercial method of plant propagation [2]. The advantages of grafting include plants that have strong roots and are resistant to diseases or pests, are resistant to drought or excess water and obtain a plant as desired. Whereas one of the disadvantages is that there is often a mismatch between the stem between the upper stem and rootstock (Pracaya, 2001). 
Pratowo (1987) states that the connection between two matching plants will produce plants that are strong and long-lived. Furthermore Nurzaini (1997) added that the factors that influence grafting are plant physiology, rootstock health, lower stem skin conditions, climate at the time of grafting, and also technical factors such as skills and expertise in the implementation of grafting and equipment used. The rootstock commonly used for splicing and attaching in principle must be able to establish a normal union and be able to support the growth of the stem without causing unwanted negative symptoms. For the rootstock that needs to be considered is the root system [3]. The union between the rootstock and the upper stem (entris) can occur if the location of attachment occurs cambium division activity and enough content The rootstock used for grafting is local citrus 'Japanese Citroen' (JC) and ough Rough Lemon '(RL) types. This rootstock is widely used in Indonesia because it has advantages, one of which is the existence of a match between the rootstock and the upper stem so as to provide a positive influence on plant survival and productivity (Poerwanto) et al., 2002). The results of the Hodijah (2012) study on the use of Understem Japanese Citroen and Rough Lemon gave the same vegetative growth to the large citrus plants of Cikoneng cultivars. Citrus fruits are generally favored by the world community, including Indonesia. Orange is a good source of vitamin C, contains $50 \mathrm{mg} / 100 \mathrm{ml}$ of fruit juice, as well as vitamin A and protein. So far the availability of citrus fruits in the country has not been sufficient [4].

The low quality and availability of citrus fruits can be seen from the value of citrus imports in Indonesia which reached 5,947,387 kg, while exports were only 54,640 $\mathrm{kg}$ (Ministry of Agriculture, 2013). Therefore, efforts need to be made to increase the production and quality of oranges. The constraints faced are the low level of technology adoption by farmers and the weak competitiveness of local oranges with imported oranges (Ridjal, 2008). One way that can be done is to improve cultivation techniques, including providing quality seeds. According to Sutami et al. (2009) [5] the key to the success of fruit development, is largely determined by the availability of quality seeds. Therefore, the development of quality seeds needs to be cultivated. Siamese and grapefruit plants can be grown and cultivated by farmers in the lowlands to the highlands.

\section{Methodology}

\subsection{Place and time of research}

This research was conducted in Belancan Village, Kintamani District, Bangli Regency with a altitude of 500 meters above sea level starting from May to September 2018.

\subsection{Tools and materials}

The tools used in this study were hoes, shovels, scales, meters, stationery, plastic pots size $20 \times 25 \mathrm{~cm}$, and planting media for a mixture of soil, husks and manure (1: 1: 1) bamboo and saws, which support research this. The ingredients used are citrus seedlings, tangerines and grapefruit entrees, chicken manure, alcohol and soil.

\subsection{Research design}

This research is a factorial experiment with Randomized Block Design (RBD) consisting of 2 factors, namely: entress length (E) and 2 citrus varieties, namely: Siamese orange (JS) and grapefruit bone (JB). The details of the treatment are as follows: The first factor is entric length $(\mathrm{E})$ which consists of 5 levels, namely: $\mathrm{E} 1=1 \mathrm{~cm}$; E2 = $2 \mathrm{~cm}$; E3 = 3 $\mathrm{cm}$; E4 $=4 \mathrm{~cm}$; E5 $=5 \mathrm{~cm}$. The second factor is 2 varieties, namely: Varieties of Siamese Orange (JS) and Orange Bali Bone (JB). 
Thus there are 10 combination treatments and repeated 3 times so that 30 experimental pots were obtained which were filled with one orange plant in each pot as a sample.

\subsection{Variable Observed}

The variables observed in this study are the growth of these grafting results as follows: (1) When shoot growth (hsp); (2) Shoot length (cm); (3) Number of shoots (strands); (4) Wet shoot buds (g); (5) open stem dry weight (g); (6) Shoots wet weight (g); (7) Open buds dry weight $(\mathrm{g})$.

\subsection{Data analysis}

The results of the observations were tested by statistical analysis using variance according to the design used, namely Randomized Block Design (RBD) and continued with a real difference test of $5 \%$ level.

\section{Result and Discussion}

\subsection{Research result}

The results of the statistical analysis on the significance of the effect of entitlement length $(\mathrm{E})$ and variety types $(\mathrm{J})$ and their interactions $(\mathrm{ExJ})$ on all observed variables are presented in Table 1.

Table 1. Significance of the effect of entitlement length (E) and citrus varieties and their interactions on all observed variables

\begin{tabular}{llccc}
\hline \multirow{2}{*}{ No. } & Variables & \multicolumn{3}{c}{ Treatment } \\
\cline { 3 - 5 } & & $\begin{array}{c}\text { Length of Entres } \\
(\mathrm{E})\end{array}$ & $\begin{array}{c}\text { Variety } \\
(\mathrm{J})\end{array}$ & $\begin{array}{c}\text { Interaction } \\
(\text { ExJ })\end{array}$ \\
\hline 1 & The appearance of shoots (HSP) & $* *$ & $\mathrm{~ns}$ & $\mathrm{~ns}$ \\
2 & Length of shoots (cm) & $* *$ & $\mathrm{~ns}$ & $\mathrm{~ns}$ \\
3 & Number of leaves shoots & $* *$ & $\mathrm{~ns}$ & $\mathrm{~ns}$ \\
& (strands) & $\mathrm{ns}$ & $\mathrm{ns}$ & $\mathrm{ns}$ \\
4 & Fresh stem weight (gram) & $\mathrm{ns}$ & $\mathrm{ns}$ & $\mathrm{ns}$ \\
5 & Dry stem weight (gram) & $* *$ & $* *$ & $*$ \\
6 & Shoot fresh weight (gram) & $* *$ & $* *$ & $*$ \\
7 & Bud dry weight (gram) & & & \\
\hline
\end{tabular}

Explanation : $\quad \mathrm{ns}=$ non significant $(\mathrm{P} \geq 0,05)$

$$
\begin{aligned}
* * & =\text { very significant }(\mathrm{P}<0,01) \\
* & =\text { significant }(\mathrm{P}<0,05)
\end{aligned}
$$

The interaction $(E \times J)$ between entress length $E$ and citrus varieties $(J)$ had no significant effect $(\mathrm{P} \geq 0.05)$ on several variables observed, except for bud wet weight variables and shoot dry weight significantly affected $(\mathrm{P}<0,05)$. The citrus varieties $(\mathrm{J})$ had no significant effect on 
the variables observed, except for the shoot wet weight variable and shoot dry weight that were very significant $(\mathrm{P}<0.01)$. Whereas in the long treatment $(\mathrm{E})$ several variables had no significant effect except for shoot length variables which had a very significant effect (P $<0.01$ ), the appearance of shoots (hsp) had a very significant effect $(\mathrm{P}<0.01)$, number of shoots ( strands) had a very significant effect $(\mathrm{P}<0.01)$, shoot wet weight (gr) had a very significant effect $(\mathrm{P}<0.01)$ and shoot dry weight $(\mathrm{g})$ had a significant effect $(\mathrm{P}<0.01)$.

\subsubsection{The appearance of shoots (HSP)}

The interaction $(E \times J)$ between entress length $E$ and citrus varieties $(J)$ had no significant effect $(\mathrm{P} \geq 0.05)$ on several variables observed, except for bud wet weight variables and shoot dry weight significantly affected $(\mathrm{P}<0,05)$. The citrus varieties $(\mathrm{J})$ had no significant effect on the variables observed, except for the shoot wet weight variable and shoot dry weight that were very significant $(\mathrm{P}<0.01)$. Whereas in the long treatment $(\mathrm{E})$ several variables had no significant effect except for shoot length variables which had a very significant effect ( $\mathrm{P}$ $<0.01$ ), the appearance of shoots (hsp) had a very significant effect $(\mathrm{P}<0.01)$, number of shoots ( strands) had a very significant effect $(\mathrm{P}<0.01)$, shoot wet weight ( $\mathrm{gr})$ had a very significant effect $(\mathrm{P}<0.01)$ and shoot dry weight $(\mathrm{g})$ had a significant effect $(\mathrm{P}<0.01)$.

\subsubsection{Length of shoots $(\mathrm{cm})$}

The results of the statistical analysis of the length of the stem shoots $(\mathrm{cm})$ showed treatment of entress length $(\mathrm{E})$ had a very significant effect $(\mathrm{P}<0.01)$ and on varieties $(\mathrm{J})$ and interactions between treatment lengths $(\mathrm{E})$ and citrus varieties $(\mathrm{J})$ not significant effect $(\mathrm{P} \geq 0.05)$. The average appearance of stem shoots (hsp) and shoot length $(\mathrm{cm})$ are presented in Table 2.

Table 2. Average appearance of shoots (hsp) and shoot length (cm)

\begin{tabular}{ccc}
\hline Treatment & The appearance of shoots (HSP) & Shoot length $(\mathrm{cm})$ \\
\hline Length of Entres & & \\
E1 & $16,17 \mathrm{a}$ & $26,53 \mathrm{~d}$ \\
E2 & $13,83 \mathrm{~b}$ & $28,82 \mathrm{c}$ \\
E3 & $12,67 \mathrm{~b}$ & $30,93 \mathrm{c}$ \\
E4 & $11,50 \mathrm{~b}$ & $37,25 \mathrm{~b}$ \\
E5 & $11,33 \mathrm{~b}$ & $43,43 \mathrm{a}$ \\
\hline BNT 5\% & 1,45 & 3,24 \\
\hline Variety $(\mathrm{J})$ & $12,93 \mathrm{a}$ & $33,22 \mathrm{a}$ \\
\hline JB & $13,27 \mathrm{a}$ & $34,24 \mathrm{a}$ \\
\hline JS & 0,92 & 2,05 \\
\hline
\end{tabular}

Description: The average value followed by the same letter in the same treatment and column, means that the difference is not significant at the level of $5 \%$. 


\subsubsection{Number of shoots (strands)}

The results of statistical analysis of the number of leaf stems (strands) showed treatment length of entres $(E)$ had a very significant effect $(P<0.01)$, whereas in citrus varieties $(J)$ and interactions between treatments of entress $(\mathrm{E})$ with citrus varieties $(\mathrm{J})$ no significant effect $(\mathrm{P} \geq 0.05)$. The average number of leaf stems (strands) is presented in table 3 .

\subsubsection{Fresh stem weight (gram)}

Statistical analysis of stem wet weight $(\mathrm{g})$ showed that the treatment of entress length (E) and treatment of citrus varieties $(\mathrm{J})$ had no significant effect $(\mathrm{P} \geq 0.05)$, and interactions that had no effect $(\mathrm{P} \geq 0.05)$. The average wet weight of the stem $(\mathrm{g})$ in the treatment of entress length (E) and treatment of citrus varieties $(\mathrm{J})$ can be seen in table 3 .

\subsubsection{Shoot fresh weight (g)}

The results of statistical analysis of stem oven dry weight $(\mathrm{g})$ on the treatment of entress length $(\mathrm{E})$ had no significant effect $(\mathrm{P} \geq 0.05)$ and on the treatment of citrus varieties $(\mathrm{J})$ and the interaction had no significant effect $(\mathrm{P} \geq 0.05)$. The average stem weight (gr) in the treatment of entres length and citrus varieties can be seen in table 3 .

Table 3. Average number of leaf stems (strands), stem fresh weight and oven oven dry weight at treatment length entres (E) and citrus plant varieties $(\mathrm{J})$

\begin{tabular}{cccc}
\hline Treatment & $\begin{array}{c}\text { Number of leaves } \\
\text { shoots (strands) }\end{array}$ & $\begin{array}{c}\text { Fresh stem weight } \\
\text { (gram) }\end{array}$ & Dry stem weight (gram) \\
\hline Length of Entres & & & \\
E1 & $6,83 \mathrm{c}$ & $10,67 \mathrm{a}$ & $4,93 \mathrm{a}$ \\
E2 & $11,00 \mathrm{~b}$ & $8,47 \mathrm{a}$ & $3,48 \mathrm{a}$ \\
E3 & $18,33 \mathrm{a}$ & $8,52 \mathrm{a}$ & $4,28 \mathrm{a}$ \\
E4 & $19,33 \mathrm{a}$ & $8,28 \mathrm{a}$ & $4,15 \mathrm{a}$ \\
E5 & $20,50 \mathrm{a}$ & $14,53 \mathrm{a}$ & $5,32 \mathrm{a}$ \\
\hline BNT 5\% & 6,33 & 7,71 & 2,02 \\
\hline Variety (J) & $15,40 \mathrm{a}$ & & $4,15 \mathrm{a}$ \\
JB & $15,00 \mathrm{a}$ & $9,04 \mathrm{a}$ & $4,72 \mathrm{a}$ \\
\hline JS & 4,01 & $11,15 \mathrm{a}$ & 1,27 \\
\hline BNT 5\% & 4,88 & \\
\hline
\end{tabular}

Description: The average value followed by the same letter in the same treatment and column, means that the difference is not significant at the level of $5 \%$. 


\subsubsection{Shoot fresh weight (gram)}

The results of statistical analysis of shoot fresh weight (grams) showed that the treatment of entress length $(E)$ and citrus varieties $(J)$ had a very significant effect $(P<0.01)$ while the interaction between treatment lengths $(\mathrm{E})$ and citrus plant varieties $(\mathrm{J})$ significant effect $(\mathrm{P}$ $<0.05)$. The average wet weight of shoots (grams) in the treatment of entress length $(\mathrm{E})$ and citrus varieties $(\mathrm{J})$ can be seen in table 4 .

\subsubsection{Bud dry weight (gram)}

The results of statistical analysis of oven dry weight $(\mathrm{g})$ showed that treatment of entress length $(\mathrm{E})$ and citrus varieties $(\mathrm{J})$ had a very significant effect $(\mathrm{P}<0.01)$, while the interaction between treatment lengths $(\mathrm{E})$ and citrus plant varieties $(\mathrm{J})$ has a significant effect $(\mathrm{P}<0.05)$. The average value of shoot dry weight $(\mathrm{g})$ in the treatment of entress length $(\mathrm{E})$ and citrus varieties $(\mathrm{J})$ is presented in Table 4.

Table 4. Average fresh shoot buds $(\mathrm{g})$ and oven dry weight shoots $(\mathrm{g})$ in the treatment of entres and citrus varieties

\begin{tabular}{ccccc|cccc}
\hline \multirow{2}{*}{ Treatment } & \multicolumn{7}{c}{ Variety (J) } \\
\cline { 2 - 8 } Length of Entres & \multicolumn{3}{c}{ Fresh Shoot Buds (g) } & \multicolumn{3}{c}{ oven dry weight shoots (g) } \\
\cline { 2 - 9 } & \multicolumn{3}{c}{ JB } & \multicolumn{3}{c}{ JS } & \multicolumn{3}{c}{ JS } \\
\hline E1 & 7,57 & (A) & 9,27 & (A) & 2,10 & (A) & 3,63 & (A) \\
& $\mathrm{b}$ & & $\mathrm{de}$ & & $\mathrm{c}$ & & $\mathrm{de}$ & \\
E2 & 31,57 & (A) & 10,07 & (B) & 5,70 & (A) & 2,70 & (A) \\
& $\mathrm{b}$ & & $\mathrm{e}$ & & $\mathrm{b}$ & & $\mathrm{e}$ & \\
E3 & 23,47 & (A) & 14,20 & (A) & 5,83 & (A) & 5,07 & (A) \\
& $\mathrm{b}$ & & $\mathrm{b}$ & & $\mathrm{bc}$ & & $\mathrm{b}$ & \\
E4 & 16,63 & (A) & 13,10 & (A) & 9,97 & (A) & 3,97 & (B) \\
& $\mathrm{b}$ & & $\mathrm{cde}$ & & $\mathrm{b}$ & & $\mathrm{cde}$ & \\
E5 & 56,97 & (A) & 20,50 & (B) & 18,20 & (A) & 5,90 & (B) \\
& $\mathrm{a}$ & & $\mathrm{a}$ & & $\mathrm{a}$ & & $\mathrm{a}$ & \\
\hline BNT 0,05 & 13,31 & & & & 5,91 & & & \\
\hline
\end{tabular}

Description: The numbers followed by the same lowercase letters in the same column (entres length of the same variety), differed not significantly at the 5\% BNT test level. The numbers followed by the same uppercase letters in the same row (types of varieties at the same length), differed not significantly at the BNT test level of $5 \%$.

\subsection{Discussion}

The interaction between the treatment of entress length and citrus plant varieties $(A \times J)$ significantly affected the shoot fresh weight and open shoot dry weight, whereas for other variables the effect was not significant. This shows that there is a meaningful collaboration between the length of enteres attached to the surface of the lower stem cambium for both enteres derived from the varieties of pomelo and siamese. So far, seed breeders are generally not very strict with the size of the entres, but based on the skill of the stickers in practicing attachment in a practical manner according to the ease of holding and also the availability of 
available entres. So that the results of this study that show the role of the length of enteres as one parameter that can be considered in an effort to improve the quality of citrus seedlings produced are included in the speed of growth and are expected to produce more quickly. As stated by Sutami et al. (2009) [5] the key to the success of fruit development, is largely determined by the availability of quality seeds. Therefore the development of quality seeds needs to be cultivated. One way that can be done is to improve cultivation techniques, including providing quality seeds.

The highest shoot fresh weight was obtained by treatment of $5 \mathrm{~cm}$ entres on the treatment of Bali citrus varieties (E5JB), which was $56.96 \mathrm{~g}$, increased by $752.87 \%$ when compared to the lowest yield treatment of $1 \mathrm{~cm}$ (E1) of citrus plant varieties (JB ) with a value of $7.57 \mathrm{~g}$. Likewise, the open shoot dry weight with the highest value was obtained from the treatment of $5 \mathrm{~cm}$ (E5) entress of grapefruit plant variety (E5JB), which was $18.20(\mathrm{~g})$, increasing by $866.67 \%$ compared to the lowest yield at $1 \mathrm{~cm}$ treatment length ( E1) Pomelo (JB) varieties with a value of $2.10 \mathrm{~g}$. Suitability of the bottom stem surface with its enteres causes attachment and adhesion between the plant material to interact more positively and accelerate the process of physiological attachment between the two components of the plant [5]. Whereas the wet weight and open shoot dry weight of grapefruit varieties compared to Siamese oranges, this is related to the size and morphology of the grapefruit plant varieties are indeed larger and higher.

\section{Conclusion}

Based on the results of research and discussion, conclusions can be drawn as follows:

4.1 The interaction between the treatment of entress length and citrus plant varieties $(\mathrm{A} \times \mathrm{J})$ significantly affected the shoot wet weight and open shoot dry weight, whereas for other variables the effect was not significant.

4.2 The highest shoot wet weight was obtained at the treatment of $5 \mathrm{~cm}$ entres on the treatment of Bali citrus varieties (E5JB), which was $56.96 \mathrm{~g}$, increased by $752.87 \%$ compared to the lowest yield treatment of $1 \mathrm{~cm}(\mathrm{E} 1)$ of citrus plant varieties. (JB) with a value of $7.57 \mathrm{~g}$.

4.3 Open shoot dry weight with the highest value was obtained by treatment of $5 \mathrm{~cm}$ (E5) entress of grapefruit varieties (E5JB), which was $18.20(\mathrm{~g})$, increased by $866.67 \%$ when compared to the lowest yield in the treatment length of $1 \mathrm{~cm}$ ( E1) Pomelo (JB) varieties with a value of $2.10 \mathrm{~g}$.

4.4 In general it is found that the length of attachment (grafting) of citrus seedlings has a role that greatly determines the success rate of making good quality seeds.

\section{Suggestion}

Based on the results of this study it is suggested as follows:

1) To get a good quality of citrus seedlings, it is important to consider the use of more than 3-5 cm in length, both in the varieties of pomelo and Siamese oranges.

2) Further research is needed on the growth of grafting results as in this study, even to get fruit yieldsya. 


\section{References}

[1] Samson, J.A.: Tropical fruits. Longman Group (1980)

[2] Supriyanto, A.: Pengelolaan Pembibitan Jeruk Bebas Penyakit dalam Kantong Plastik. Denpasar: Sub Balai Penelitian Hortikultura Tlekung. Vol. 15 (1990)

[3] Hartman, H.T., \& Kester, D.E.: Plant Propagation, Principles and Practices (4th Ed). Prentice Hall International Inc, New Jersey (1983)

[4] Abdurahman., Sudiyanti., \& Basuno.: Teknik Okulasi Jeruk Manis Dengan Perlakuan Masa Penyimpanan Dan Media Pembungkus Entres Yang Berbeda. Jurnal Buletin Teknik Pertanian. Vol. 12(1) (2007)

[5] Sutami., Mursyid, A., \& Noor, G.M.S.: Pengaruh Umur Batang Bawah Dan Panjang Entris Terhadap Keberhasilan Sambungan Bibit Jeruk Siam Banjar Label Biru. Jurnal Agroscientiae. Vol. 16(2), pp. 1-9 (2009) 